\title{
LOCATIONAL STUDY OF JUNIOR HIGH SCHOOL AND MADRASAH TSANAWIYAH USING GEOGRAPHY INFORMATION SYSTEM (GIS) AT CEPOGO SUBDISTRICT BOYOLALI DISTRICT IN 2016
}

\author{
MS Khabibur Rahman ${ }^{1)}$, Jumadi ${ }^{2)}$ \\ ${ }^{1), 2)}$ Universitas Veteran Bangun Nusantara Sukoharjo, Indonesia \\ e-mail : khabib_ynwa@yahoo.co.id
}

\begin{abstract}
This research was conducted to find out and analyze the coverage of junior high school and madrasah tsanawiyah services to the user community in Cepogo District. The research used descriptive geographical research method using map analysis and the data collection methods used were documentation studies and field observations. The data collection technique in this study used a population that includes all junior secondary schools and Islamic elementary schools in Cepogo sub-district with primary data in the form of school locations obtained through field measurements using GPS (Global Potential System) and secondary data obtained from agencies authority and results from previous studies. The data analysis technique used was secondary data analysis techniques and map analysis techniques using buffer analysis. The results showed that there was a difference between supply (number of elementary school graduates) and demand (study group) in which supply was greater than demand. In addition, the coverage of education facilities at the junior high school / MTs level in Cepogo District is in accordance with the minimum standards of the national education minister's regulation no. 24 of 2007 concerning the maximum distance to education facilities, which is no more than $6 \mathrm{~km}$ with no hazardous track.
\end{abstract}

Keywords: Locational study, GIS, education facilities, service coverage

\section{A. INTRODUCTION}

The problem of Indonesia's population today, aside of having large population, also has serious problems in terms of education, especially on the issue of low children's education. In fact, as stated in the Preamble of the 1945 Constitution, education is a very important matter and severely needs special attention since one of the objectives of national development is to educate the life of the nation.
On the other hand, the rapid technological improvement especially information systems, can be used as an alternative solution to solve problems on the earth surface, both physical and social fields, such as education, economics, politics, environment and culture through a spatial approach. One technique used to generate spatial information is through the GIS technique. GIS is an information system that combines spatial and attribute data 
which can be added, stored, manipulated, and recalled according to the user needs (Rahman, Rohsulina, \& Kuswanto, 2018). The information produced by GIS analysis is performed in a map and can be used to support decision making system for land use (Rahman \& Hamid, 2018), tourism ((Partono \& Rahman, 2016), tourism development (Partono \& Rahman, 2017), health (Rahman, Rohsulina, \& Kuswanto, 2018), education facilities planning (Rahman \& Rohsulina, 2015), natural resource, enviroment, and transportation.

Regarding the provision of educational facilities, the Minister of National Education Regulation No. 24 of 2007 concerning Standard Facilities and Infrastructures for Junior High School (later called Sekolah Menengah Pertama or SMP in Bahasa) / Madrasah Tsanawiyah (Islamic schooling equivalent to SMP) states that one school can serve a maximum of 2000 people and students can reach the school's location by walking with a maximum of $6 \mathrm{~km}$ through the harmless track. For this reason, this study was conducted to find out and analyze the coverage of junior high school services and madrasah tsanawiyah in Cepogo District based on these government regulations. Furthermore, this study is expected as a useful reference to plan the development of educational facilities as well as to solve educational problems related to population problems in Cepogo District.

\section{B. METHODS}

This research was conducted in Cepogo Subdistrict, Boyolali Regency which consisted of 15 villages, namely: Cepogo, Bakulan, Cabeankunthi, Wonodoyo, Sukabumi, Candigatak, Genting, Gedangan, Gubug, Jelok, Jombong, Jombong, Kembangkuning, Sumbung, Paras, and Mliwis.

The study used a descriptive geographic research method with map analysis. Descriptive geographic method is a research method to solve problems by describing a fact-based situation that produces spatial descriptive data. According to Rahman \& Rohsulina (2015), the spatial analysis emphasizes the elements of distance, interaction, and movement. Geographic descriptive in this study is description of the number of primary school graduates (supply) and the large number of study groups / school capacity (demand), description of the distribution of the secondary school and Madrasah tsanawiyah, school capacity, affordability of first secondary school services and Madrasah tsanawiyah, the distribution pattern of the first secondary school and Madrasah tsanawiyah, and the 
optimal location for the establishment of the first secondary school and Madrasah tsanawiyah.

The data collection method in this study was through documentation and field observation studies. The data collection technique in this study used a population that includes all junior secondary schools and Islamic elementary schools in Cepogo District. Primary data collected was the location of the school obtained through field measurements using a GPS (Global Potential System). Secondary data was obtained from authorized institutions and from the results of previous studies which is population data of Boyolali Regency (source: Central Bureau of Statistics), Map of RBI sheets 1408-244, 1408-333 and 1408-611 scale 1: 25,000, BAKOSULTANAL, the number of study groups and the number of SMP / MTs in Cepogo District, and the number of graduates of the primary school in Cepogo District (source: Education and Culture Office of Boyolali District).

The data analysis technique used was secondary data analysis techniques and map analysis techniques in which secondary data analysis technique (tabulation) produces School Distribution Patterns in Boyolali District and map analysis technique produces the coverage of school services through buffer analysis. The designed map is important to record, display, analyze, and to understand the spatial relationship between objects (Rohsulina et al, 2015).

\section{RESULTS}

To find out the pattern of distribution of educational facilities whether has been in accordance with the Minister of Education no. 24 of 2007, the regulation about the minimum standards on the provision of education facilities at the junior high school / MTs level is described below:

1. One SMP / MTs has a minimum of 3 study groups and a maximum of 24 study groups.

2. One SMP / MTs with three study groups serving a maximum of 2000 people. For services for residents of more than 2000 people, additional study groups are conducted at existing schools, and if more than 24 study groups are carried out the construction of new SMP / MTs.

3. One sub-district is served by a minimum of one SMP / MTs which can accommodate all elementary schools (later called SD or Sekolah Dasar in Bahasa) / MI (Islamic schooling equivalent to elementary school) graduates in the subdistrict. 
4. One permanent and remote settlement group with many residents of more than 1,000 lives served by one junior high school / MTs within the distance for students who walk a maximum of $6 \mathrm{~km}$ through a non-hazardous trajectory.

\section{a. Service Coverage based on Supply and Demand}

To find out how the scope of school services for junior high school / MTs level in the Cepogo Subdistrict area, we need some data to facilitate the calculation of the School Level of Service, namely:

1) Data on the number of elementary school and MI and the number of class VI students

2) Data on the number of SMP / MTs and study groups or capacity of SMP / MTs

Data 1), and 2) were then analyzed to obtain answers regarding the suitability of supply and demand in the District of Cepogo and then concluded how the service level of junior high school / MTs school in Cepogo District.

From the observations, it was known that the number of class VI students that can be used as a supply for SMP and MTs was 881 students, while the total capacity of SMP / MTs was 19 study groups from 4 schools. In accordance with the minimum standard of education, each study group consists of 30-40 students. If each class has 40 students, the overall capacity is in accordance with the number of classes and the number of students per class for class VII students is 19 times 40 multiplied by 760 students.

From the calculation based on the number of study groups multiplied by the maximum number of students in one study group, it was found that the number of SMP / MTs demand in Cepogo District was 760 students. Based on the calculation of supply and demand above, we can see that there is still a difference between the number of supply and demand of 121 students or more or less requires an additional 3 study groups.

Based on Minister of Education Regulation No. 4 of 2007 that each district is served by a minimum of one SMP / MTs that can accommodate all SD / MI graduates in the sub-district. From the calculation of supplay and demand above, the difference between supply and demand in Cepogo Subdistrict is 121 students, therefore to meet the minimum standards in the Ministry of Education no. 4 of 2007 required the addition of demand (study groups) of 3 study groups to be able to accommodate all elementary school graduates in Cepogo District. 


\section{b. Service Coverage Based on Maximum} Mileage

In addition to service coverage analysis based on supply and demand, it is necessary to analyze the service range based on the maximum distance to go to educational facilities. In accordance with the minimum standards of school services in the National Education Ministry no. 24 of 2007 , it is stated that:

A group of permanent and remote settlements with a population of more than 1,000 lives is served by one junior high school / MTs within the distance for students who walk a maximum of $6 \mathrm{~km}$ through a non-hazardous track.

The service coverage analysis based on the maximum distance traveled to education facilities will be carried out by using a geographic information system with a buffer technique. In this study buffer analysis using Arcgis 10.1 software.

Buffer is a function that can be found in any GIS application including ArcGIS. This facility is often used in analytical work related to environmental "regulation" (Prahasta, 2002). Buffer is another form of analytical technique that identifies the relationship between one point and the area around or called proximity analysis. Proximity analysis is an analysis process that is often used in determining sites / land for the purposes of marketing strategies in business / trade.

Anatomically, buffer is a form of zone that leads out from an object mapping whether it is a point, line, or area (Prahasta, 2002). By creating a buffer, an area that covers or protects a spatial object in a map (buffered object) is formed with a certain distance. So zones formed in this line are used to identify the spatial proximity of an object map to the objects around it.

The buffer analysis used in this study was buffering the location points of junior high school / MTs level in Cepogo District with a radius of $6 \mathrm{~km}$. The buffering results illustrate the condition of the range of SMP/MTs services. To find out more clearly the description of School buffering results can be seen in Figure 1. 


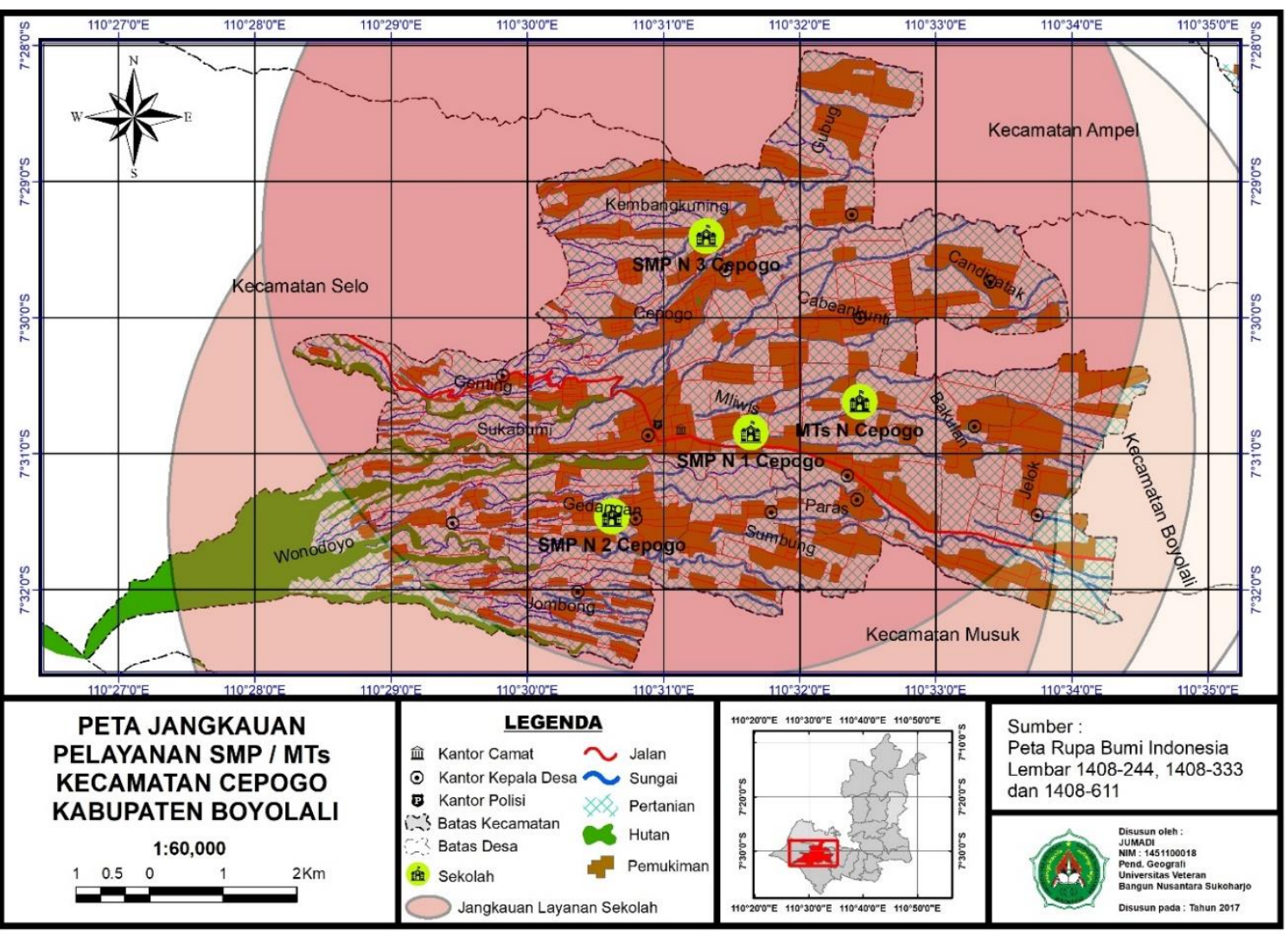

Figure 1. Map of the range of junior high school services

From Figure 1, it can be seen that Cepogo has 4 junior high school / MTs that are spread over different sides within the region. The results of buffering analysis using GIS showed that the entire area of Cepogo has reachable education facilities in accordance with minimum service standards. Even the range of their services is able to reach out its other surrounding areas.

\section{CONCLUSION}

The discussion about the coverage services of education facilities at SMP / MTs level in Cepogo, Boyolali can be summarized as follows: a. Based on the calculation of supply and demand in Cepogo, there is a difference between supply (number of elementary school graduates) and demand (study group), which exceeds supply of 121 students or in other words there is a shortage of approximately 3 study groups to accommodate all elementary school graduates in the District Cepogo.

b. Based on buffering analysis, according to the maximum distance traveled to education facilities, the range of educational facilities at secondary school/ MTs level in Cepogo has been in accordance with the minimum standards in 
the national education minister's regulation no. 24 of 2007 which is no more than $6 \mathrm{~km}$ with no hazardous terrain

Based on the conclusions above, then author has several suggestions including:

a. To increase the coverage of education facilities at SMP / MTs level in Cepogo, it needs to add 3 study groups to accommodate all existing elementary school graduates.

b. It is unnecessary to have additional junior high school / MTs level units, because the service coverage of school locations has been in accordance with the minimum standards of the national education minister's regulation no. 24 of 2007.

\section{E. REFERENCE}

Partono, B., \& Rahman, M. K. (2016). Pemetaan Sistem Informasi Geografis untuk Pemetaan Wisata Alam dan Budaya sebagai Usaha Perkembangan Kabupaten Sukoharjo. Simposium Nasional RAPI XV.

Partono, B., \& Rahman, M. K. (2017). Development of Tourism Site on the Narrow Land (Case Study Dam Colo, Nguter District of Sukoharjo) . International Journal of Research in
Tourism and Hospitality (IJRTH), 29.

Prahasta, Eddy (2002). Sietem Informasi Geografis : Konsep - Konsep Dasar Informasi Geografis. Bandung : Informatika Bandung

Peraturan menteri pendidikan no. 24 Tahun 2007 mengenai standar sarana dan prasarana untuk Sekolah dasar / madrasah ibtidaiyah ( SD/MI ), sekolah menengah pertama / madrasah tsanawiyah ( SMP/MTs ) dan sekolah menengah atas / madrasah aliyah ( SMA/MA )

Rahman, M. K., \& Hamid, A. (2018). The Use of Satellite Imagery for Land Use Updating . International Conference on Applied Science and Engineering.

Rahman, M. K., Rohsulina, P., \& Kuswanto, E. (2018). GIS Application for Health Database System. Atlantis Press.

Rahman, M. K., \& Rohsulina, P. (2015). Pemetaan Sarana Prasarana Sd Negri Di Kecamatan Sukoharjo Berdasarkan Permendiknas Nomor 24 Tahun 2007 . Geoedukasi, 54

Rohsulina, P et al (2015). Analisis Persebaran Daerah Asal Mahasiswa Universitas Veteran Bangun Nusantara dengan Menggunakan Sistem Informasi Geografis (SIG). Geoedukasi, 18. 